\title{
$\leqslant$ Research Square \\ Patient perspectives on treatment, care and
rehabilitation after hip fracture: A meta-aggregative systematic review
}

Charlotte Abrahamsen ( $\square$ cabrahamsen@health.sdu.dk)

University of Southern Denmark https://orcid.org/0000-0002-3700-289X

Birgitte Nørgaard

Syddansk Universitet

Research article

Keywords: Hip fracture, quality of life, systematic review, patient perspective

Posted Date: December 12th, 2019

DOI: https://doi.org/10.21203/rs.2.18631/v1

License: (1) (1) This work is licensed under a Creative Commons Attribution 4.0 International License. Read Full License

Version of Record: A version of this preprint was published at International Journal of Orthopaedic and Trauma Nursing on April 1st, 2021. See the published version at https://doi.org/10.1016/j.ijotn.2020.100811. 


\section{Abstract}

Background: Hip fracture surgery is a distressing and life-changing event for patients. The treatment, care and rehabilitation of hip fracture patients governed by evidence-based recommendations, the patients' preferences are often not represented. The aim of this systematic review is to identify elderly hip fracture patients' priorities during their care trajectory.

Methods: A meta-aggregative approach was applied to present findings on patient perspectives. Data were extracted from the findings in the Results section of each study, categorized by similarity in meaning by both authors as either "health-related outcomes" or "healthcare-related experiences". The quality of the presented evidence was evaluated, and all studies were assessed using the Critical Appraisal Skills Programme (CASP) checklist.

Results: Sixteen qualitative studies met the inclusion criteria. The health-related outcomes category included: 1) symptoms and complications, 2) physical health, 3) mental health and 4) social relationships and 5) personal goals. Healthcare-related experiences revolved around: 1) waiting time, 2) information, 3) being treated with respect, 4) participation and 5) discharge.

Conclusions: This systematic review provides an overview of hip fracture patients' perspectives on important aspects of care, treatment and training during their trajectory, thereby contributing to the development of a patient-derived measure of hip fracture.

\section{Background}

The consequences of a hip fracture can be considerable. Mortality rates of up to $10 \%$ during admission [1] and $20-36 \%$ after 12 months [2,3] are documented. Between 40 and $60 \%$ of hip fracture survivors recover their pre-fracture functional level while $40-70 \%$ regain their level of independence for basic activities of daily living $[4,5]$. Impaired mobility alongside reduced social independence affects quality of life [6-8].

Several continental and national orthopaedic associations have published evidence-based recommendations for the treatment, care and rehabilitation of hip fracture patients, including recommendations on mobilization strategies, the timing of surgery, pain management, post-operative prevention, rehabilitation programmes and patient information $[9,10]$. Patient's preferences are not represented in the guidelines, even though this issue is central to evidence-based practice [11]. Furthermore, healthcare professionals' perceptions of quality of care and quality of life may differ from patients' perceptions [12], as the former tend to focus on clinical factors whereas the latter focus on the impact on their lives [13].

A systematic inclusion of the patient perspective in patient pathways could be secured by implementing patient-reported outcome instruments (PROM). However, for PROM instruments to reflect the patients' perspectives, it is essential to develop and use patient-derived instruments $[14,15]$. Where PROM instruments truly reflect patient perspectives, they have been shown to improve patient-provider communication and patient satisfaction [16-18]. There is also growing evidence that well-implemented PROM instruments improve the monitoring of treatment response and enhance the detection of unrecognized problems [16]. 
Despite much work on hip fracture, this is the first systematic overview of research on the patient perspective to be published. The aim of this paper was to identify the factors considered essential by elderly hip fracture patients. Its core topics - treatment, care and rehabilitation - emerged from the context.

\section{Methods}

The protocol was registered exclusively with PROSPERO (ID CRD42018091981), which is accessible at www.crd.york.ac.uk/PROSPERO.

\section{Meta-aggregative approach}

Using a meta-aggregative approach, we strove for a reliable representation of the authors' findings. A reinterpretation of the findings was not our aim as the meta-aggregative approach is pragmatic, aiming for immediate usability of findings [19].

\section{Search strategy}

An information specialist was consulted for the design of our search strategy and the identification of databases and keywords.

The following electronic bibliographic databases were searched by the first author (C.A.) on April 10, 2018: MEDLINE via PubMed, PsycINFO, EMBASE and CINAHL, using block building strategy as well as searching grey literature in PsycEXTRA, OpenSIGLE and HMIC database. Pearl growing strategy was subsequently used to examine the reference lists of relevant studies, dissertations and conference abstracts.

Search terms were structured using the SPIDER framework. However, its design and evaluation aspects were deselected due to highly restricted searches. Table 1 exemplifies the search strategy for Cinahl.

\section{Inclusion criteria}

\section{Study selection}

Retrieved studies were imported into Endnote (https://endnote.com/). Doublets were removed, both prior to importation to the web-based reference programme Covidence (www.covidence.org) and in Covidence. In Covidence, both reviewers (C.A. and B.N.) independently screened and identified studies meeting the inclusion criteria. Any disagreement between the reviewers concerning the eligibility of studies was resolved through a joint survey to reach consensus. Studies that met the inclusion criteria were retrieved for full text analysis. The process is shown in Figure 1.

\section{Data extraction}


Study characteristics were extracted by the first author, including bibliographic information (author, year and country), study aim, data collection methods, time and place of interview, sampling strategy, inclusion and exclusion criteria, participant characteristics and data analysis techniques (Table 2). Data on patients' perspectives were extracted by both authors as first-order constructs (participants' citations) and secondorder constructs (researcher interpretation, including themes, subthemes and statements) [20].

\section{Quality appraisal}

The quality assessment was based on the Critical Appraisal Skills Programme (CASP) checklist for qualitative studies [21] and user guidelines as described by Butler et al., 2016 [22]. In the scoring, 1 point was allocated for Yes, 0.5 points for Can't tell (unsure) and 0 points for No. To ensure a rigorous and fair assessment, we considered all italicized prompts listed under each question in the checklist, giving particular emphasis to Question 3 (the presence of a justification of research design), Question 7 (clear statements concerning the researchers' detailed explanations of the research to participants) and to Question 8 (the presence of in-depth description of the analysis process).

All articles were assessed independently by both authors. Disagreement occurred only concerning unclear criteria fulfilment, which was discussed until consensus was reached. Data are shown in Table 2.

\section{Analysis}

Data were analysed by both authors, using a meta-aggregative approach. The analytical strategy included the extraction of findings from the Results section of each study, in terms of citations, statements, categories and themes described by the authors of the primary-level studies. Based on the recommendations of Pearson et al. (2004), each finding was assigned a level of evidence according to its quality (Table 4 in Supplementary). The data extraction was initially approached in an open and explorative fashion (inductively). The data were subsequently categorized according to similarity of meaning, as judged by both authors and grouped for final synthesis as either health-related outcomes or healthcare-related experiences.

\section{Results}

We identified 2045 articles: CINAHL $(n=446)$, EMBASE $(n=1087)$, PubMed $(n=379)$, PsycINFO $(n=125)$ and PsycEXTRA, OpenSIGLE and HMIC database $(n=7)$. A search of reference lists and abstracts of the included studies identified a single study. In Endnote and Covidence, 427 and 183 duplicates, respectively, were excluded. A total of 1436 articles were retrieved and assessed for eligibility; 1326 articles were excluded after a review of their titles and abstracts, leaving 110 studies for full-text reading. Sixteen studies met the inclusion criteria (Figure 1).

\section{Study characteristics}


Six studies had been conducted in Sweden, three in the UK, two in Canada; the remaining five in Denmark, Norway, New Zealand, Australia or the USA. The studies covered data gathered at admission [23, 24], two weeks [25], one month [26], two to four months [27-30] or six to 12 months after discharge from hospital [3133]. One study had a time frame from three months to 22 years after fracture [34]; the remaining four studies gave no indication of the time of interviewing [35-38]. In total, 286 participants were interviewed, 211 females and 59 males aged 6599 years (Table 2).

Various techniques were employed for data collection: semi-structured, in-depth and telephone interviewing. The data analysis techniques appeared to be heterogeneous; the most frequently used were phenomenological approaches, content or thematic analysis.

\section{Quality assessment}

With CASP quality scores of 6.5-9.5, the quality of the studies ranged from low (below 7.5), to moderate (7.5-9) to high (9-10) [22]. Methodological shortcomings mainly concerned the omission of considerations on the researcher-participants relationship and ethical issues (CASP, Questions 6 and 7). Several studies provided no clear justification of methodological choices, in which case Can't tell was assigned. Details are presented in Table 3.

\section{That hip fracture patients find important}

\section{Health-related outcomes}

Health-related outcomes included 1) symptoms and complications, 2) physical health, 3) mental health and 4) social relationships and 5) personal goals.

\section{1) Symptoms and complications}

Mentioned in several studies [23, 26, 30-33, 35-37], pain provided the core theme of two studies [35, 37]. Pain occurred immediately after the injury [37], and for some continued to be a problem 6-12 months after the injury [26, 31, 33]\{, $1997 \# 1449\}$. Patients described their pain in various ways, e.g. as intense or stabbing, in the hip, radiating towards the groin, numbness of the leg [35]; however, it was typically described simply as extreme and intense. Patients perceived the hip pain to be worst during movement; when they laid still, the pain disappeared except initially in the hospital stay, when it was constant [35]. Pain was cited as one of the main reasons for avoiding exercise, thus hindering recovery.

Unexpected postoperative medical or surgical complications were among the other symptoms and complications mentioned by patients as major barriers to recovery [31, 33]. Complications also included hallucinating, sleeping problems, constipation, a lack of appetite and low blood count [35, 36], fatigue and tiredness [26, 28, 32, 33] and subsequent falls [31]. 
When addressing leg-specific symptoms and complications, swelling [35], stiffness [26], reduced leg length [28] and problems with balance, strength and speed were pinpointed [28, 32, 33]. The patients saw these factors, or pre-existing health issues, combined with hip fracture, as impediments to recovery [31, 38].

\section{2) Physical health}

The patients' mobility was reduced, and they felt restricted by both the fracture and the physical symptoms and complications listed above [26, 28, 32, 35, 37].

Mobilization in particular was found to be difficult and harrowing during the first few days [35]. Everyday functions that had earlier been taken for granted, such as walking freely, had suddenly become difficult. The patients were thus wary of performing common daily activities, such as using a low armchair, worrying that they might not be able to rise from it, or cleaning, doing the laundry, shopping, going for a walk outdoors, driving a car or using public transportation $[26,28,38]$. Overall, the unreliability of their body and their sense of fragility left them feeling vulnerable $[23,26,27,29,30,37]$.

For some patients, the physical consequences of the hip fracture persevered 12 months after the injury [32].

\section{3) Mental health}

Patients described the hip fracture as a shocking, or even life-shattering event that had put their life on hold $[23,26,28,29]$. They addressed their new situation very differently, however; some were able to stay active or seek others' help in trying to remain in control of their life, while others felt resignation, hesitant and unable to actively take control and plan for the future $[23,26-28,30,33,38]$. Regaining control was perceived crucial to recovery.

Physical limitations caused insecurity, confidence loss and mistrust of own physical ability. Many reported worries about falling again [26-28, 30, 32, 35, 37]. They were also anxious about relapse [30] and treatment [36], adverse events and overmedication [35]. Concern was also expressed about further complications [38], their future ability to walk [23], dependency $[23,27,38]$, the discharge and return to the home $[23,25,27,35]$ and the future in general $[26,29,38]$.

Some patients' mood was negatively affected by the changed life situation brought about by the limitations in agility and their increased insecurity and fear [32]. They felt a sense of meaninglessness and had lost hope for the future [26, 32]. Some reported being depressed [29] or losing "the spark of life" [26, 32].

Patients saw it as essential to maintain a positive attitude and engage fully in the recommended rehabilitation activities $[25,31]$.

\section{4) Social relationships}

After hip fracture, patients spoke of a more restricted everyday life and being prevented from performing normal activities, such as cooking, washing, cleaning, shopping and gardening, which caused periodic 
feelings of dependence on others [26,37]. For those living with a spouse or other family members, family was described as being instrumental for support with daily activities and encouragement to engage in rehabilitative exercises [33]. Many singles enjoyed support from neighbours [35]. Some spoke of their belief that their recovery process had been facilitated by others' actions $[29,31]$. Yet, they found it difficult to balance between their need and expectations for help and not burdening their family [28, 30, 32, 34, 35, 38].

As they became housebound, the physical limitations had led to an isolated everyday life for some patients $[26,28,32,37]$, and the lack of energy made them abstain from inviting or visiting neighbours and friends [28]. Overall, their life had suffered from the diminished social contact [32].

\section{5) Personal goals}

The patients' goals included returning home, regaining independence, getting well and being able to walk again. These goals were perceived useful to facilitate the recovery process [31]. Hip fracture patients, regardless of health status or ability, expressed a strong desire to recuperate [23, 32]. However, patients admitted from and returning to their own homes were especially determined to regain their independence [25, $28-31,37]$ and return to normality $[27,29,30,34]$.

Patients described a need for information on what to expect, including time to recover and train and to keep on fighting to achieve their goals $[25,29]$. Unrealistic expectations would increase the risk of disappointment and dissatisfaction, some said [33].

Most patients expected a return to life as it was before the injury, although some spoke of having had to gradually lower their expectations and adjust to life with disability [26, 32, 34].

\section{Healthcare-related experiences}

Several studies mention patients' experiences in relation to waiting time [35], information [23-25, 30, 32, 33, $35,36,38]$, being treated with respect [25], participation $[24,25,34,36]$ and discharge $[23-25,31,35,38]$.

\section{1) Waiting time}

Waiting times was a core theme of one study, which reported that elderly patients with hip fracture found the waiting time for surgery protracted and stressful. It is noted, however, that when it was time for surgery, many patients still did not feel mentally prepared because they felt that "everything happened very quickly"[35].

\section{2) Information}

Eight studies indicated as especially important various aspects of information, such as the need for it [24, 38], the lack of it [33] as well as information content [23-25, 27, 32, 35, 38] and method [27]. 
Patients indicated their interest in information on a range of issues, such as hip fracture [23,27,35], surgery [35], current and potential complications [35, 38], rehabilitation and training [23,32, 35], care decisions [24] and discharge [25]. Being informed also covered feedback, advice or reassurance from healthcare professionals regarding progress [27]. Overall, there was a strong desire to be able to know what to expect during the course of treatment [25].

However, hip fracture patients differed in their conceptions of their need for information [23]. Some were aware of the importance of information and requested it. Others appreciated and were grateful for any information offered, but made no requests for elaboration, although they seemed to want this [23]. The causes of their reluctance are unknown, although the authors conjecture this could stem from not knowing what to ask about [33]. Others showed no interest in receiving or discussing potentially useful information [23].

Patients frequently reported the need for more information about their condition, about what to do and how to act, $[23,30,38]$. Among the oldest persons, many were made to feel cognitively floundering, disempowered, a lack of confidence and anxious about their capabilities as a result of not being informed or not recalling being informed, or being unable to understand the information provided [30]. Yet, some patients were satisfied with the given information and experienced its calming effect [35].

Overall, patients expressed a wish for sufficient information at the right time [32]. Mentioning e.g. verbal and written information, weekly information sessions on the ward about hip fracture, they requested it be given from various sources, and employing different modes [35].

\section{3) Being treated with respect}

The patients' sense of well-being appeared to depend on dialogue and their experience of empathy [36]. One informant expressed her humiliation at not being treated humanely [25].

\section{4) Participation}

Four of the included studies referred to participation and involvement as important issues. Participation was requested with regard to processes during hospitalization and discharge planning [25] and in relation to own healthcare [24]. Overall, many patients perceived their participation as lacking [24, 25, 36]. The younger among the patients, and those living independently prior to the hip fracture, were more likely to insist on being involved [34].

\section{5) Discharge}

Returning home was considered a main goal by the informants [31], but several felt insecure or even anticipated discharge with anxiety $[23,25,35]$. In a study in which being "ready or not" was a core theme, an informant vividly described the rushed nature of her discharge and her feeling of being unprepared [24]. 
Patients' sense of insecurity was aggravated by limited information about the pathway and what to expect after discharge. This left them unable to image their situation on returning home [25]. There was a widespread desire to be involved in discharge plans [25].

\section{Level of evidence}

As recommended by Pearson et al. (2004), each finding was assigned a level to indicate the quality of evidence. Three levels were used: (a) Unequivocal ("evidence is beyond reasonable doubt and includes findings that are factual, directly reported/observed and not open to challenge"); (b) Credible (evidence, while interpretative, is plausible in light of the data and theoretical framework; conclusions can be logically inferred from the data but, because the findings are essentially interpretative, these conclusions are open to challenge"); and (c) Unsupported ("findings are not supported by the data and none of the other level descriptors apply") [39].

A total of 140 findings were made. The majority (88) were categorized as level a evidence; of those, 51 justified inclusion as core themes or subthemes, while 37 were included as citations. Level b evidence was also well represented (42), whereas level c evidence was relatively scarce (10). Level a evidence was represented in both PRO and PREM categories; however, the majority of level a (72) and level b (35) findings related to PRO. Details on evidence levels are shown in Table 4 (supplementary).

\section{Discussion}

This review reports patient perspectives that were collected from a time immediately following hip fracture to weeks, months or even years later. Despite the diversity of types of healthcare settings and location across the world, including in-hospital and rehabilitation trajectories, we identified a number of shared themes of importance to hip fracture patients.

Using an open and explorative approach, the themes were categorized as either 1) health-related outcomes or 2) healthcare-related experiences.

\section{Health-related outcomes}

Hip fracture patients were found to prioritize outcome domains related to 1) symptoms and complications, 2) physical health, 3) mental health and 4) quality of life, including personal goals and social relationships. All four domains were strongly represented by the themes and sub-themes of the primary studies.

We found that hip fracture patients focus primarily on regaining physical functioning, mobility and independence. The physical symptoms and complications, pre-existing health issues, combined with hip fracture, cause patients to feel restricted in their ability to move, thus hindering recovery. This leads to physical immobility and dependency on others. Another important factor affecting recovery is the patient's mental condition; while some are able to retain a hopeful attitude and overcome obstacles, others lose hope and manage recovery less well. Patients' ability to "take control" and handle their fear of falling and anxiety 
about the future are crucial to recovery. Recovery is facilitated also by social support, whether from a spouse, family, friends or neighbours, as they help with daily activities and encourage engagement with rehabilitation exercises. Recovery likewise depends on the individual's expectations and personal goals, such as preferred activities in future everyday life and whether returning to normality or independence is a primary goal.

Our findings corroborate those of a previous study, which found that hip fracture patients' evaluation of their recovery emphasize factors such as pain and leg-shortening outcomes, mobility, mental well-being, fear of falling, the ability to perform day-to-day activities, self-care and level of independence (37). Griffith et al. (2015) has admonished that fracture be viewed in the context of age-related decline and that its impact cannot be disentangled from the impact of other health issues. Furthermore, that recovery is influenced by the patients' pre-fracture state and their ability to adapt during recovery. It thus appears that age, pre-fracture conditions and personal goals are conditions of life that should be recognized as important in hip fracture patients' recovery.

The diversity of factors that hip fracture patients find important calls for individualized approaches and solutions according to the patient's physical, mental and social conditions, as well as their different expectations and goals. Staff and significant others play a substantial role in rehabilitation [40]. Sensitivity to the patient's experience of worries and obstacles is vital in healthcare professionals' support of older people who strive to recover after hip fracture. By encouraging the patients to plan and set goals based on their own wishes for the future, healthcare professionals can further support the patient in regaining functional ability and independence [40].

\section{Healthcare-related experiences}

Experiences in relation to healthcare concern a number of aspects, such as access and waiting time, confidence and trust in health professionals, information and communication, involvement in treatment decisions, availability of staff, being treated with dignity and respect, food, physical environments and overall satisfaction [41]. These aspects relate to patients' experiences and to the process of care rather than its effect (PREM). In our review, we established that patients typically report on waiting time, information, being treated with respect, participation and discharge; four aspects that are generally recognized as important. Hip fracture patients are, however, particularly preoccupied with experiences in relation to discharge.

\section{Implications for clinical practice}

Data on patient experience and outcomes are susceptible to both qualitative and quantitative analysis. The qualitative methods used for some of the studies included here contribute to an in-depth understanding of matters of particular concern to hip fracture patients. Where patterns and trends are to be described and compared from large data samples, structured quantitative methods based by questionnaires eliciting patient experience (PREM) and health outcomes (PROM) are common [41].

Generic and domain-specific PROM tools, such as the SF-36, the EQ-5D and the Barthel index, are used to evaluate quality of life and health in several patient categories, including hip fracture patients [14]. Whereas 
generic and domain-specific PROM tools are relevant for assessing a range of general health issues, they are not specific to elderly hip fracture patients. Our findings provide a systematic overview of hip fracture patients' perspectives on important aspects of care, treatment and rehabilitation and contribute to the development of patient-derived hip fracture-specific PROM and PREM tools that are based on patients' perspectives.

\section{Strength and limitations}

The immediate applicability of its results are among the benefits of the meta-aggregative approach [19]. It is furthermore relatively insensitive to the widely different analytical frameworks of the included studies. A third benefit is the quality control conducted at the findings level (unequivocal, credible and unsupported).

This systematic review was based on a review protocol and was conducted independently by two researchers with no preferences towards its outcomes. It nonetheless entails the same potential weaknesses as similar reviews, including uncertainty whether all relevant articles were retrieved. However, the consultation of information specialist expertise supports the thoroughness and adequacy of our search.

\section{Conclusion}

This systematic review provides an overview of hip fracture patients' perspectives on important aspects of care, treatment and training during their trajectory, thereby contributing to the development of a patientderived measure of hip fracture. Above all, hip fracture patients give priority to regaining physical functioning, mobility and independence. Their social network, a surplus of mental resources and the reduction of pain and complications are seen as vital. They concede that recovery likewise depends on their commitment to realizing their own expectations and personal goals.

\section{Declarations}

\section{Ethics approval and consent to participate}

Not applicable

\section{Consent for publication}

Not applicable

\section{Availability of data and materials}

Not applicable

\section{Competing interest}


The authors declare that they have no competing of interests.

\section{Funding}

No funding was obtained for this study

\section{Authors contributions}

Both authors (CA \& BN) are responsible for concept and design, analysis and interpretation of data and preparation of manuscript. All authors have read and approved the manuscript.

\section{Acknowledgements}

We gratefully acknowledge the supervision regarding the PROSPERO protocol provided by OPEN (the Odense Patient data Explorative Network).

\section{Authors information}

Charlotte Abrahamsen (CA), MHS, PhD, Assistant Professor, Department of Public Health, University of Southern Denmark \& Department of Orthopaedic Surgery, Kolding Hospital a part of Hospital Lillebaelt, Denmark; Birgitte Nørgaard (BN), MScN, PhD, Ass. Professor, Department of Public Health, University of Southern Denmark

\section{Abbreviations}

CASP: Critical appraisal skills programme

PRO: patient-reported outcomes

PROM: patient-reported outcome measures

PREM: patient-reported experience measures

\section{References}

1. Sanz-Reig, J., J. Salvador Marin, J. M. Perez Alba, J. Ferrandez Martinez, D. Orozco Beltran and J. F. Martinez Lopez (2017). "Risk factors for in-hospital mortality following hip fracture." Rev Esp Cir Ortop Traumatol61(4): 209-215.

2. Mundi, S., B. Pindiprolu, N. Simunovic and M. Bhandari (2014). "Similar mortality rates in hip fracture patients over the past 31 years." Acta Orthop $85(1)$ : 54-59. 
3. Abrahamsen, B., T. van Staa, R. Ariely, M. Olson and C. Cooper (2009). "Excess mortality following hip fracture: a systematic epidemiological review." Osteoporosis International20(10): 1633-1650.

4. Bertram, M., R. Norman, L. Kemp and T. Vos (2011). "Review of the long-term disability associated with hip fractures." Inj Prev17(6): 365-370.

5. Dyer, S. M., M. Crotty, N. Fairhall, J. Magaziner, L. A. Beaupre, I. D. Cameron, et al. (2016). "A critical review of the long-term disability outcomes following hip fracture." BMC geriatrics16(1): 158.

6. Alexiou, K. I., A. Roushias, S. E. Varitimidis and K. N. Malizos (2018). "Quality of life and psychological consequences in elderly patients after a hip fracture: a review." Clin Interv Aging13: 143-150.

7. Hall, S. E., J. A. Williams, J. A. Senior, P. R. Goldswain and R. A. Criddle (2000). "Hip fracture outcomes: quality of life and functional status in older adults living in the community." Aust N Z J Med30(3): 327332.

8. Peeters, C. M., E. Visser, C. L. Van de Ree, T. Gosens, B. L. Den Oudsten and J. De Vries (2016). "Quality of life after hip fracture in the elderly: A systematic literature review." Injury_47(7): 1369-1382.

9. Chesser, T. J. S. and R. Handley (2017). "Update of NICE guidance for hip fractures in adults." Hip Int27(5): 413-414.

10. Roberts, K. C., W. T. Brox, D. S. Jevsevar and K. Sevarino (2015). "Management of Hip Fractures in the Elderly." JAAOS - Journal of the American Academy of Orthopaedic Surgeons23(2): 131-137.

11. Satterfield, J. M., B. Spring, R. C. Brownson, E. J. Mullen, R. P. Newhouse, B. B. Walker, et al. (2009). "Toward a Transdisciplinary Model of Evidence-Based Practice." The Milbank Quarterly87(2): 368-390.

12. Abuosi, A. A. (2015). "Patients versus healthcare providers' perceptions of quality of care: Establishing the gaps for policy action." Clinical Governance: An International Journal20(4): 170-182.

13. Clark, M. (2005). "Healthcare professionals' versus patients' perspectives on diabetes...second article in our psychology series." Journal of Diabetes Nursing 9(3): 87-91.

14. Haywood, K. L., J. Brett, E. Tutton and S. Staniszewska (2016). "Patient-reported outcome measures in older people with hip fracture: a systematic review of quality and acceptability." Quality of Life Research.

15. Reeve, B. B., K. W. Wyrwich, A. W. Wu, G. Velikova, C. B. Terwee, C. F. Snyder, et al. (2013). "ISOQOL recommends minimum standards for patient-reported outcome measures used in patient-centered outcomes and comparative effectiveness research." Quality of Life Research22(8): 1889-1905.

16. Chen, J., L. Ou and S. J. Hollis (2013). "A systematic review of the impact of routine collection of patient reported outcome measures on patients, providers and health organisations in an oncologic setting." BMC Health Serv Res 13: 211.

17. Yang, L. Y., D. S. Manhas, A. F. Howard and R. A. Olson (2018). "Patient-reported outcome use in oncology: a systematic review of the impact on patient-clinician communication." Support Care Cancer26(1): 41-60.

18. Kotronoulas, G., N. Kearney, R. Maguire, A. Harrow, D. Di Domenico, S. Croy, et al. (2014). "What is the value of the routine use of patient-reported outcome measures toward improvement of patient outcomes, processes of care, and health service outcomes in cancer care? A systematic review of controlled trials." Journal of clinical oncology32(14): 1480-1501. 
19. Hannes, K. and C. Lockwood (2011). "Pragmatism as the philosophical foundation for the Joanna Briggs meta-aggregative approach to qualitative evidence synthesis." J Adv Nurs67(7): 1632-1642.

20. Toye, F., K. Seers, N. Allcock, M. Briggs, E. Carr and K. Barker (2014). "Meta-ethnography 25 years on: challenges and insights for synthesising a large number of qualitative studies." BMC Med Res Methodol14: 80.

21. "NHS. Critical appraisal skills programme (CASP): appraisal tools, 2003."

22. Butler, A., H. Hall and B. Copnell (2016). "A Guide to Writing a Qualitative Systematic Review Protocol to Enhance Evidence-Based Practice in Nursing and Health Care." Worldviews Evid Based Nurs13(3): 241249.

23. Olsson, L. E., A. E. Nystrom, J. Karlsson and I. Ekman (2007). "Admitted with a hip fracture: patient perceptions of rehabilitation." J Clin Nurs16(5): 853-859.

24. Toscan, J., B. Manderson, S. M. Santi and P. Stolee (2013). "'Just another fish in the pond": the transitional care experience of a hip fracture patient." Int J Integr Care13: e023.

25. Jensen, C. M., A. C. Smith, S. Overgaard, U. K. Wiil and J. Clemensen (2017). "'"If only had I known": a qualitative study investigating a treatment of patients with a hip fracture with short time stay in hospital." Int J Qual Stud Health Well-being12(1): 1307061.

26. Zidén, L., C. Wenestam and M. Hansson-Scherman (2008). "A life-breaking event: early experiences of the consequences of a hip fracture for elderly people." Clinical Rehabilitation22(9): 801-811.

27. McMillan, L., J. Booth, K. Currie and T. Howe (2014). '"Balancing risk' after fall-induced hip fracture: the older person's need for information." Int J Older People Nurs9(4): 249-257.

28. Gesar, B., C. Baath, H. Hedin and A. Hommel (2017). "Hip fracture; an interruption that has consequences four months later. A qualitative study." International Journal of Orthopaedic \& Trauma Nursing26: 43-48.

29. Bruun-Olsen, V., A. Bergland and K. E. Heiberg (2018). "'I struggle to count my blessings": recovery after hip fracture from the patients' perspective." BMC Geriatr18(1): 18.

30. Booth, J., K. Currie and T. Howe (2012). "A grounded theory of taking control after fall-induced hip fracture." Disability and Rehabilitation34(26): 2234-2241.

31. Young, Y. and B. Resnick (2009). "Don't worry, be positive: improving functional recovery 1 year after hip fracture." Rehabil Nurs34(3): 110-117.

32. Zidén, L., M. H. Scherman and C. Wenestam (2010). "The break remains - elderly people's experiences of a hip fracture 1 year after discharge." Disability \& Rehabilitation32(2): 103-113.

33. Sims-Gould, J., S. Stott-Eveneshen, L. Fleig, M. McAllister and M. C. Ashe (2017). "Patient Perspectives on Engagement in Recovery after Hip Fracture: A Qualitative Study." J Aging Res2017: 2171865.

34. Healee, D. J., A. McCallin and M. Jones (2017). "Restoring: How older adults manage their recovery from hip fracture." International Journal of Orthopaedic \& Trauma Nursing26: 30-35.

35. Hommel, A., M. L. Kock, J. Persson and E. Werntoft (2012). "The Patient's View of Nursing Care after Hip Fracture." ISRN Nurs2012: 863291.

36. Aronsson, K., I. Björkdahl and B. W. Sundström (2014). "Prehospital emergency care for patients with suspected hip fractures after falling -- older patients' experiences." Journal of Clinical Nursing23(21/22): 
3115-3123.

37. Archibald, G. (2003). "Patients' experiences of hip fracture." Journal of Advanced Nursing44(4): 385-392.

38. Wykes, C., J. Pryor and B. Jeeawody (2009). "The concerns of older women during inpatient rehabilitation after fractured neck of femur...including commentary by Voshaar RO, Proctor R, and Olsson L." International Journal of Therapy \& Rehabilitation16(5): 261-270.

39. Pearson, A. (2004). "Balancing the evidence: incorporating the synthesis of qualitative data into systematic reviews." JBI Reports2(2): 45-64.

40. Rasmussen, B. and L. Uhrenfeldt (2016). "Establishing well-being after hip fracture: a systematic review and meta-synthesis." Disabil Rehabil38(26): 2515-2529.

41. Coulter, A., R. Fitzpatrick and J. Cornwell (2009). Measures of patient experience in hospitals: purpose, methods and uses.

\section{Tables}

Table 1. Example of search strategy in CINAHL

\begin{tabular}{|c|c|c|c|c|c|c|}
\hline $\begin{array}{c}\text { S } \\
\text { Sample }\end{array}$ & & $\begin{array}{c}\mathbf{P} \\
\text { Phenomenon of } \\
\text { interest }\end{array}$ & & $\begin{array}{c}\text { D } \\
\text { Design }\end{array}$ & $\begin{array}{c}\text { E } \\
\text { Evaluation }\end{array}$ & $\begin{array}{l}\text { R } \\
\text { Research } \\
\text { type }\end{array}$ \\
\hline Elderly 65 years or above & AND & Hip fracture & AND & & & $\begin{array}{c}\text { Qualitative } \\
\text { studies }\end{array}$ \\
\hline $\begin{array}{l}\text { (frail* or sarcopeni* or elder* or senior* } \\
\text { or gerontolog* or geriatric* or veteran* } \\
\text { or old or patient*) OR (MH "Aged+" or } \\
\text { MH "Frail Elderly" or MH "Geriatrics") }\end{array}$ & & $\begin{array}{l}\text { (MH "Hip Fractures+") } \\
\text { OR (fractured hip or hip } \\
\text { fracture*) OR ((fracture* }^{\text {or broke or broken) and }} \\
\text { (hip or hips)) }\end{array}$ & & & & $\begin{array}{l}\text { (MH } \\
\text { "Qualitative } \\
\text { Studies+") } \\
\text { OR } \\
\text { (MH } \\
\text { "Interviews+") } \\
\text { OR } \\
\text { (qualitative } \\
\text { or } \\
\text { Interview*) }\end{array}$ \\
\hline
\end{tabular}

A rerun of searches on January 31, 2019, added no studies.

\section{Table 2. Study characteristics}




\begin{tabular}{|c|c|c|c|c|c|c|c|}
\hline $\begin{array}{l}\text { Author, } \\
\text { location } \\
\text { and year of } \\
\text { publication }\end{array}$ & Aim & $\begin{array}{l}\text { Design/data } \\
\text { collection } \\
\text { method }\end{array}$ & $\begin{array}{l}\text { Inclusion and } \\
\text { exclusion criteria }\end{array}$ & $\begin{array}{l}\text { Time and } \\
\text { place of } \\
\text { interview }\end{array}$ & $\begin{array}{l}\text { Sampling } \\
\text { strategy }\end{array}$ & $\begin{array}{l}\text { Participants' } \\
\text { characteristics } \\
\text {-Sex } \\
\text {-Age } \\
\text {-Living }\end{array}$ & $\begin{array}{l}\text { Data analysis } \\
\text { techniques }\end{array}$ \\
\hline $\begin{array}{l}\text { Archibald, } \\
\text { G. } \\
\text { UK } \\
2003 \\
{[37]}\end{array}$ & $\begin{array}{l}\text { Explore } \\
\text { participants' } \\
\text { experiences to gain } \\
\text { insight into how to } \\
\text { improve nursing } \\
\text { care of people after } \\
\text { hip fracture }\end{array}$ & $\begin{array}{l}\text { In-depth } \\
\text { interviewing }\end{array}$ & $\begin{array}{l}\text { Patients } \\
\text { undergoing } \\
\text { rehabilitation } \\
\text { after hip fracture } \\
\text { repair over } 65 \\
\text { years, with } \\
\text { subacute care } \\
\text { needs. } \\
\text { No cognitive } \\
\text { impairment }\end{array}$ & $\begin{array}{l}\text { Not } \\
\text { documented }\end{array}$ & $\begin{array}{l}\text { Purposeful } \\
\text { sampling }\end{array}$ & $\begin{array}{l}5 \text { participants } \\
4 \text { females, } \\
1 \text { male }\end{array}$ & $\begin{array}{l}\text { Phenomenological } \\
\text { approach }\end{array}$ \\
\hline $\begin{array}{l}\text { Olsson, L } \\
\text { et al. } \\
\text { Sweden } \\
2007 \\
{[23]}\end{array}$ & $\begin{array}{l}\text { Describe patients' } \\
\text { perception of their } \\
\text { situation and views } \\
\text { on own } \\
\text { responsibilities in } \\
\text { rehabilitation } \\
\text { process }\end{array}$ & Interviewing & $\begin{array}{l}\text { Patients aged } 70 \\
\text { years or older, } \\
\text { non-institutional } \\
\text { residence and } \\
\text { acute surgery for } \\
\text { hip fracture. } \\
\text { Excluded if severe } \\
\text { illness, cognitive } \\
\text { impairment or } \\
\text { dementia, or } \\
\text { pathological } \\
\text { fracture }\end{array}$ & $\begin{array}{l}\text { As soon } \\
\text { after } \\
\text { operation as } \\
\text { informants } \\
\text { felt strong } \\
\text { enough. } \\
\text { In patients' } \\
\text { room or in a } \\
\text { secluded } \\
\text { area of ward }\end{array}$ & $\begin{array}{l}\text { Strategical } \\
\text { sampling }\end{array}$ & $\begin{array}{l}13 \text { participants } \\
11 \text { females, } \\
2 \text { males } \\
\text { Age } 71-93 \\
\text { years (mean } \\
\text { age } 81 \text { years) }\end{array}$ & $\begin{array}{l}\text { Phenomenological } \\
\text { approach }\end{array}$ \\
\hline $\begin{array}{l}\text { Zidén, L et } \\
\text { al. } \\
\text { Sweden } \\
2008 \\
{[26]}\end{array}$ & $\begin{array}{l}\text { Explore and } \\
\text { describe } \\
\text { consequences of } \\
\text { acute hip fracture } \\
\text { as } \\
\text { experienced by } \\
\text { home-dwelling } \\
\text { elderly people } \\
\text { immediately on } \\
\text { discharge }\end{array}$ & $\begin{array}{l}\text { Semistructured } \\
\text { interviewing }\end{array}$ & $\begin{array}{l}\text { Acute hip fracture } \\
\text { including people } \\
\text { aged } 65 \text { or older } \\
\text { living in own } \\
\text { home, no } \\
\text { cognitive } \\
\text { impairment and } \\
\text { able to } \\
\text { understand and } \\
\text { speak Swedish }\end{array}$ & $\begin{array}{l}1 \text { month } \\
\text { after } \\
\text { discharge } \\
\text { In their own } \\
\text { homes }\end{array}$ & $\begin{array}{l}\text { Purposeful } \\
\text { selection }\end{array}$ & $\begin{array}{l}18 \text { participants } \\
16 \text { female, } 2 \\
\text { males } \\
\text { Age } 65-99 \\
\text { years (mean } \\
\text { age } 80.6 \text { years) }\end{array}$ & $\begin{array}{l}\text { A } \\
\text { phenomenological } \\
\text { method }\end{array}$ \\
\hline $\begin{array}{l}\text { Wykes, C } \\
\text { et al. } \\
\text { Australia } \\
2009 \\
{[38]}\end{array}$ & $\begin{array}{l}\text { Explore impact of } \\
\text { fractured neck of } \\
\text { femur on } \\
\text { independent } \\
\text { women's lives and } \\
\text { identify their } \\
\text { concerns }\end{array}$ & $\begin{array}{l}\text { In-depth } \\
\text { interviewing }\end{array}$ & $\begin{array}{l}\text { Inpatient } \\
\text { rehabilitation } \\
\text { following } \\
\text { fractured neck of } \\
\text { femur, aged 60-85 } \\
\text { years, living alone } \\
\text { and independently } \\
\text { before injury, } \\
\text { converse fluently } \\
\text { in English and } \\
\text { cognitively intact }\end{array}$ & $\begin{array}{l}\text { Not } \\
\text { documented }\end{array}$ & $\begin{array}{l}\text { Recruited by a } \\
\text { senior nurse if } \\
\text { meeting } \\
\text { inclusion } \\
\text { criteria }\end{array}$ & $\begin{array}{l}5 \text { participants } \\
5 \text { females } \\
\text { Independent } \\
\text { prior to hip } \\
\text { fracture }\end{array}$ & Thematic analysis \\
\hline $\begin{array}{l}\text { Young, Y } \\
\text { and } \\
\text { Resnick, B }\end{array}$ & $\begin{array}{l}\text { Explore perceptions } \\
\text { of older adults }\end{array}$ & $\begin{array}{l}\text { In-person } \\
\text { interviewing, } \\
\text { using a }\end{array}$ & $\begin{array}{l}\text { Age } 65 \text { years or } \\
\text { older with hip } \\
\text { fracture, }\end{array}$ & $\begin{array}{l}1 \text { year post } \\
\text { hip fracture }\end{array}$ & $\begin{array}{l}\text { Convenience } \\
\text { sampling }\end{array}$ & $\begin{array}{l}62 \text { participants } \\
76 \% \text { female }\end{array}$ & Content analysis \\
\hline
\end{tabular}




\begin{tabular}{|c|c|c|c|c|c|c|c|}
\hline $\begin{array}{l}\text { USA } \\
2009 \\
{[31]}\end{array}$ & $\begin{array}{l}\text { about their } \\
\text { functional recovery }\end{array}$ & $\begin{array}{l}\text { thematic } \\
\text { survey }\end{array}$ & $\begin{array}{l}\text { community- } \\
\text { dwelling }\end{array}$ & $\begin{array}{l}\text { Place of } \\
\text { interview not } \\
\text { documented }\end{array}$ & & $\begin{array}{l}\text { Age } 65-91 \\
\text { years } \\
45 \% \text { cohabiting }\end{array}$ & \\
\hline $\begin{array}{l}\text { Zidén, L et } \\
\text { al. } \\
\text { Sweden } \\
2010 \\
{[32]}\end{array}$ & $\begin{array}{l}\text { Explore experienced } \\
\text { long-term } \\
\text { consequences of a } \\
\text { hip fracture and the } \\
\text { conceptions of } \\
\text { what influences } \\
\text { recovery }\end{array}$ & $\begin{array}{l}\text { Semistructured } \\
\text { interviewing }\end{array}$ & $\begin{array}{l}\text { Hip fracture, } 65 \\
\text { years or older, } \\
\text { community- } \\
\text { dwelling at time } \\
\text { of injury, } \\
\text { no life-threatening } \\
\text { disease or severe } \\
\text { cognitive } \\
\text { impairment, able } \\
\text { to understand and } \\
\text { speak Swedish }\end{array}$ & $\begin{array}{l}1 \text { year after } \\
\text { discharge } \\
\text { In their own } \\
\text { homes }\end{array}$ & $\begin{array}{l}\text { Purposeful } \\
\text { selection }\end{array}$ & $\begin{array}{l}15 \text { participants } \\
13 \text { female, } 2 \\
\text { males } \\
\text { Age } 66-93 \\
\text { years (mean } \\
\text { age } 80 \text { years) }\end{array}$ & $\begin{array}{l}\text { A } \\
\text { phenomenological } \\
\text { method }\end{array}$ \\
\hline $\begin{array}{l}\text { Booth, J et } \\
\text { al. } \\
\text { UK } \\
2012 \\
{[30]}\end{array}$ & $\begin{array}{l}\text { Explore post } \\
\text { discharge concerns } \\
\text { of older people } \\
\text { after fall-induced } \\
\text { hip fracture repair }\end{array}$ & $\begin{array}{l}\text { Semistructured } \\
\text { interviewing }\end{array}$ & $\begin{array}{l}\text { Sustaining a fall- } \\
\text { induced hip } \\
\text { fracture, } \\
\text { discharge within } \\
\text { previous } 3 \\
\text { months }\end{array}$ & $\begin{array}{l}\text { Between } 2 \\
\text { and } 12 \\
\text { weeks after } \\
\text { discharge } \\
\text { In } \\
\text { participants' } \\
\text { own homes }\end{array}$ & $\begin{array}{l}\text { Purposive } \\
\text { sampling }\end{array}$ & $\begin{array}{l}19 \text { participants } \\
15 \text { female, } 4 \\
\text { males } \\
67 \text { - } 89 \text { years } \\
\text { (mean age } 79 \\
\text { years) } \\
10 \text { lived alone, } \\
9 \text { cohabiting }\end{array}$ & $\begin{array}{l}\text { Constant } \\
\text { comparative } \\
\text { method }\end{array}$ \\
\hline $\begin{array}{l}\text { Hommel, A } \\
\text { et al. } \\
\text { Sweden } \\
2012 \\
{[35]}\end{array}$ & $\begin{array}{l}\text { Illuminate patients' } \\
\text { view of nursing care } \\
\text { during hip fracture } \\
\text { treatment }\end{array}$ & $\begin{array}{l}\text { Semistructured } \\
\text { interviewing }\end{array}$ & $\begin{array}{l}\text { Hospitalized for } \\
\text { hip fracture, } \\
\text { proficient in } \\
\text { Swedish, } \\
\text { admission } \\
\text { through new } \\
\text { pathway, passed } \\
\text { cognitive function } \\
\text { test (SPMSQ) }\end{array}$ & $\begin{array}{l}\text { Time of } \\
\text { interview not } \\
\text { documented } \\
\text { At a } \\
\text { separate } \\
\text { room at } \\
\text { hospital } \\
\text { ward }\end{array}$ & $\begin{array}{l}\text { Convenience } \\
\text { sampling }\end{array}$ & $\begin{array}{l}10 \text { participants } \\
9 \text { female, } 1 \\
\text { male } \\
\text { Mean age } 78 \\
\text { years }\end{array}$ & Content analysis \\
\hline $\begin{array}{l}\text { Toscan, J } \\
\text { et al. } \\
\text { Canada } \\
2013 \\
{[24]}\end{array}$ & $\begin{array}{l}\text { Explore single hip } \\
\text { fracture patients' } \\
\text { experience of } \\
\text { transitional care } \\
\text { over complete care } \\
\text { trajectory }\end{array}$ & $\begin{array}{l}\text { Semistructured } \\
\text { interviewing } \\
\text { (plus current } \\
\text { literature and } \\
\text { participant } \\
\text { observation) }\end{array}$ & $\begin{array}{l}\text { Being a hip } \\
\text { fracture patient, } \\
\text { expected to } \\
\text { undergo multiple } \\
\text { transitions in } \\
\text { care, over age of } \\
65 \text { years and } \\
\text { proficient in } \\
\text { written and } \\
\text { spoken English }\end{array}$ & $\begin{array}{l}\text { From } \\
\text { admission to } \\
\text { home care } \\
\text { (4 different } \\
\text { settings) - } \\
\text { several } \\
\text { interviews } \\
\text { over a period } \\
\text { of } 3.5 \\
\text { months }\end{array}$ & $\begin{array}{l}\text { Purposive } \\
\text { sampling }\end{array}$ & $\begin{array}{l}1 \text { participant } \\
\text { Female } \\
\text { In her } 80 \mathrm{~s} \\
\text { Living alone }\end{array}$ & $\begin{array}{l}\text { Inductive } \\
\text { approach }\end{array}$ \\
\hline $\begin{array}{l}\text { McMillan, } \\
\text { L et al. } \\
\text { UK } \\
2014 \\
{[27]}\end{array}$ & $\begin{array}{l}\text { Explore concerns of } \\
\text { older people } \\
\text { following surgical } \\
\text { intervention for fall- } \\
\text { induced hip fracture }\end{array}$ & $\begin{array}{l}\text { Semistructured } \\
\text { interviewing }\end{array}$ & $\begin{array}{l}\text { Fall-induced hip } \\
\text { fracture, } \\
\text { discharge within } \\
\text { previous } 3 \\
\text { months }\end{array}$ & $\begin{array}{l}\text { Between } 2 \\
\text { and } 3 \\
\text { months after } \\
\text { discharge }\end{array}$ & $\begin{array}{l}\text { Purposive } \\
\text { sampling }\end{array}$ & $\begin{array}{l}19 \text { participants } \\
15 \text { female, } 4 \\
\text { males }\end{array}$ & $\begin{array}{l}\text { Constant } \\
\text { comparative } \\
\text { method }\end{array}$ \\
\hline
\end{tabular}




\begin{tabular}{|c|c|c|c|c|c|c|c|}
\hline & $\begin{array}{l}\text { to enhance } \\
\text { understanding and } \\
\text { awareness of } \\
\text { issues that may } \\
\text { impact recovery } \\
\text { and rehabilitation }\end{array}$ & & & $\begin{array}{l}\text { In } \\
\text { participants' } \\
\text { own homes }\end{array}$ & & $\begin{array}{l}\text { Age } 67 \text { - } 89 \\
\text { years (mean } \\
\text { age } 79 \text { years) } \\
10 \text { lived alone, } \\
9 \text { cohabiting }\end{array}$ & \\
\hline $\begin{array}{l}\text { Aronsson, } \\
\text { K et al. } \\
\text { Sweden } \\
2014 \\
{[36]}\end{array}$ & $\begin{array}{l}\text { Describe and } \\
\text { interpret older } \\
\text { patients' lived } \\
\text { experiences of } \\
\text { prehospital } \\
\text { emergency care in } \\
\text { cases of suspected } \\
\text { hip fracture after } \\
\text { falling }\end{array}$ & $\begin{array}{l}\text { In-depth } \\
\text { interviewing }\end{array}$ & $\begin{array}{l}\text { Suspected hip } \\
\text { fracture after } \\
\text { falling, } \\
\text { prehospital } \\
\text { emergency care } \\
\text { by ICP (age } 65 \\
\text { years or older), } \\
\text { private residence, } \\
\text { no dementia or } \\
\text { other } \\
\text { disorientation } \\
\text { conditions }\end{array}$ & $\begin{array}{l}\text { Time of } \\
\text { interview not } \\
\text { documented } \\
\text { In } \\
\text { participants' } \\
\text { own homes }\end{array}$ & $\begin{array}{l}\text { Participants } \\
\text { were selected in } \\
\text { EMS electronic } \\
\text { patient care } \\
\text { record system } \\
\text { for a period of } \\
\text { three months }\end{array}$ & $\begin{array}{l}10 \text { participants } \\
7 \text { female, } 3 \\
\text { males } \\
\text { Age } 68-91 \\
\text { years (mean } \\
\text { age } 80 \text { ) }\end{array}$ & $\begin{array}{l}\text { Analysed for } \\
\text { meanings }\end{array}$ \\
\hline $\begin{array}{l}\text { Gesar, B et } \\
\text { al. } \\
\text { Sweden } \\
2017 \\
{[28]}\end{array}$ & $\begin{array}{l}\text { Describe adaptation } \\
\text { to daily life of } \\
\text { previously healthy } \\
\text { persons } 65 \text { years or } \\
\text { older, four months } \\
\text { after hip fracture }\end{array}$ & $\begin{array}{l}\text { Semistructured } \\
\text { interviewing }\end{array}$ & $\begin{array}{l}\text { Independent life } \\
\text { before fracture, } \\
\text { aged } 65 \text { years or } \\
\text { older, previously } \\
\text { healthy (none or } \\
\text { mild systemic } \\
\text { disease), no } \\
\text { cognitive } \\
\text { impairment, able } \\
\text { to speak and } \\
\text { understand } \\
\text { Swedish }\end{array}$ & $\begin{array}{l}4 \text { months } \\
\text { after hip } \\
\text { fracture } \\
\text { In their } \\
\text { homes or at } \\
\text { a café }\end{array}$ & $\begin{array}{l}\text { Sampling } \\
\text { strategy not } \\
\text { documented }\end{array}$ & $\begin{array}{l}25 \text { participants } \\
22 \text { female, } 3 \\
\text { males } \\
17 \text { were aged } \\
80 \text { years or } \\
\text { older }\end{array}$ & $\begin{array}{l}\text { Inductive content } \\
\text { analysis }\end{array}$ \\
\hline $\begin{array}{l}\text { Healee, D } \\
\text { et al. } \\
\text { New } \\
\text { Zealand } \\
2017 \\
{[34]}\end{array}$ & $\begin{array}{l}\text { Generate theory to } \\
\text { explain recovery } \\
\text { from hip fracture, } \\
\text { specifically from } \\
\text { perspective of older } \\
\text { adults }\end{array}$ & $\begin{array}{l}\text { Semistructured } \\
\text { interviewing }\end{array}$ & Hip fracture & $\begin{array}{l}\text { Hip fracture } \\
\text { just over } 3 \\
\text { months ago } \\
\text { up to } 22 \\
\text { years } \\
\text { Place of } \\
\text { interview not } \\
\text { documented }\end{array}$ & $\begin{array}{l}\text { Recruitment } \\
\text { through } \\
\text { informal } \\
\text { networking, } \\
\text { notices in } \\
\text { relevant } \\
\text { centres, } \\
\text { intermediaries } \\
\text { and through } \\
\text { rehabilitation } \\
\text { units of a local } \\
\text { hospital }\end{array}$ & $\begin{array}{l}16 \text { participants } \\
\text { Age } 70-92 \\
\text { years } \\
\text { Half were in a } \\
\text { partnership } \\
\text { Half had co- } \\
\text { existing health } \\
\text { conditions }\end{array}$ & $\begin{array}{l}\text { Constant } \\
\text { comparative } \\
\text { analysis }\end{array}$ \\
\hline $\begin{array}{l}\text { Jensen, } \\
\text { CM et al. } \\
\text { Denmark } \\
2017 \\
{[25]}\end{array}$ & $\begin{array}{l}\text { Describe hip } \\
\text { fracture patients' } \\
\text { experiences and } \\
\text { explore if they felt } \\
\text { empowered and } \\
\text { able to perform } \\
\text { self-care in short- } \\
\text { time hospital stay } \\
\text { pathways (STSH) }\end{array}$ & $\begin{array}{l}\text { Interviewing } \\
\text { and telephone } \\
\text { interviewing }\end{array}$ & $\begin{array}{l}\text { Discharged to } \\
\text { own home, } \\
\text { independent prior } \\
\text { to hip fracture } \\
\text { (able to walk and } \\
\text { perform everyday } \\
\text { life without } \\
\text { significant } \\
\text { assistance from } \\
\text { municipality), hip }\end{array}$ & $\begin{array}{l}2 \text { weeks } \\
\text { after } \\
\text { discharge } \\
\text { and 3-5 } \\
\text { months after } \\
\text { primary } \\
\text { interview } \\
\text { Place of } \\
\text { interview not }\end{array}$ & $\begin{array}{l}\text { Patients with } \\
\text { different } \\
\text { working } \\
\text { experience, } \\
\text { different ages } \\
\text { and sex. }\end{array}$ & $\begin{array}{l}10 \text { participants } \\
8 \text { female, } 2 \\
\text { males } \\
\text { Age } 67-92 \\
\text { years } \\
\text { Independent } \\
\text { prior to hip }\end{array}$ & $\begin{array}{l}\text { A } \\
\text { phenomenological } \\
\text { approach }\end{array}$ \\
\hline
\end{tabular}




\begin{tabular}{|c|c|c|c|c|c|c|c|}
\hline & & & $\begin{array}{l}\text { fracture was a } \\
\text { fragile fracture }\end{array}$ & documented & & fracture & \\
\hline $\begin{array}{l}\text { Sims- } \\
\text { Gould, J et } \\
\text { al. } \\
\text { Canada } \\
2017 \\
\text { [33] }\end{array}$ & $\begin{array}{l}\text { Examine hip } \\
\text { fracture patients' } \\
\text { experiences, } \\
\text { focusing on their } \\
\text { perceptions of } \\
\text { recovery period and } \\
\text { engagement in } \\
\text { rehabilitation }\end{array}$ & $\begin{array}{l}\text { Telephone } \\
\text { interviewing }\end{array}$ & $\begin{array}{l}\text { Community- } \\
\text { dwelling older } \\
\text { adults aged } 65 \\
\text { years and older } \\
\text { with hip fracture }\end{array}$ & $\begin{array}{l}6 \text { months } \\
\text { and } 12 \\
\text { months after } \\
\text { hip fracture } \\
\text { Interview } \\
\text { location not } \\
\text { disclosed }\end{array}$ & $\begin{array}{l}\text { Participants in } \\
\text { RCT study }\end{array}$ & $\begin{array}{l}50 \text { participants } \\
32 \text { female,18 } \\
\text { male } \\
21 \text { living } \\
\text { alone,29 } \\
\text { cohabiting }\end{array}$ & $\begin{array}{l}\text { A deductive } \\
\text { approach followed } \\
\text { by an inductive } \\
\text { approach }\end{array}$ \\
\hline $\begin{array}{l}\text { Bruun- } \\
\text { Olsen, V et } \\
\text { al. } \\
\text { Norway } \\
2018 \\
{[29]}\end{array}$ & $\begin{array}{l}\text { Explore experience } \\
\text { of recovery process } \\
\text { in elderly hip } \\
\text { fracture patients } \\
\text { enrolled in ongoing } \\
\text { RCT - issues } \\
\text { related to } \\
\text { experience of } \\
\text { facilitators and } \\
\text { barriers }\end{array}$ & $\begin{array}{l}\text { Semistructured } \\
\text { interviewing }\end{array}$ & $\begin{array}{l}\text { Home-dwelling } \\
\text { prior to hip } \\
\text { fracture, and } \\
\text { competent to give } \\
\text { informed consent }\end{array}$ & $\begin{array}{l}\text { 3-4 months } \\
\text { after } \\
\text { fracture } \\
\text { In home }\end{array}$ & $\begin{array}{l}\text { Strategically } \\
\text { according to } \\
\text { age, sex, and } \\
\text { participation in } \\
\text { rehabilitation }\end{array}$ & $\begin{array}{l}8 \text { participants } \\
6 \text { female, } 2 \\
\text { males } \\
\text { Age } 69 \text { - } 91 \\
\text { years }\end{array}$ & $\begin{array}{l}\text { Systematic text } \\
\text { condensation }\end{array}$ \\
\hline
\end{tabular}

\section{Table 3. Quality assessment using CASP}




\begin{tabular}{|c|c|c|c|c|c|c|c|c|c|c|}
\hline $\begin{array}{l}\text { Clear } \\
\text { statement } \\
\text { of aim }\end{array}$ & $\begin{array}{l}\text { Qualitative } \\
\text { methodology } \\
\text { appropriate }\end{array}$ & $\begin{array}{l}\text { Research } \\
\text { design } \\
\text { appropriate }\end{array}$ & $\begin{array}{l}\text { Recruitment } \\
\text { strategy } \\
\text { appropriate }\end{array}$ & $\begin{array}{l}\text { Data } \\
\text { collection } \\
\text { addressed } \\
\text { research } \\
\text { issue }\end{array}$ & $\begin{array}{l}\text { Researcher- } \\
\text { participant } \\
\text { relationship } \\
\text { adequately } \\
\text { considered }\end{array}$ & $\begin{array}{l}\text { Ethical } \\
\text { issues taken } \\
\text { into } \\
\text { consideration }\end{array}$ & $\begin{array}{l}\text { Data } \\
\text { analysis } \\
\text { sufficiently } \\
\text { rigorous }\end{array}$ & $\begin{array}{l}\text { Clear } \\
\text { statement } \\
\text { of findings }\end{array}$ & $\begin{array}{l}\text { Valuable } \\
\text { research }\end{array}$ & Score \\
\hline Yes & Yes & Can't tell & Can't tell & Can't tell & No & Yes & Yes & Yes & Yes & 7.5 \\
\hline Yes & Yes & Yes & Yes & Yes & Can't tell & Yes & Yes & Yes & Yes & 9.5 \\
\hline Yes & Yes & Can't tell & Yes & Yes & Can't tell & Yes & Yes & Yes & Can't tell & 8.5 \\
\hline Yes & Yes & Yes & Yes & Yes & Yes & no & Yes & Yes & Yes & 9.0 \\
\hline Yes & Yes & Can't tell & Can't tell & Yes & Can't tell & no & Yes & Yes & Can't tell & 7.0 \\
\hline Yes & Yes & Can't tell & Yes & Yes & Can't tell & Can't tell & Yes & Yes & Can't tell & 8.0 \\
\hline Yes & Yes & Can't tell & Yes & Yes & No & Can't tell & Yes & Yes & Yes & 8.0 \\
\hline Yes & Yes & Can't tell & Yes & Yes & Can't tell & Yes & Can't tell & Yes & Can't tell & 8.0 \\
\hline Yes & Yes & Yes & Yes & Yes & Yes & Can't tell & Yes & Yes & Yes & 9.5 \\
\hline Yes & Yes & Yes & Yes & Yes & no & Can't tell & Yes & Yes & Yes & 8.5 \\
\hline Yes & Yes & Yes & Yes & Can't tell & Yes & Yes & Yes & Yes & Yes & 9.5 \\
\hline Yes & Yes & Can't tell & Can't tell & Yes & no & Yes & Can't tell & Yes & Yes & 7.5 \\
\hline
\end{tabular}




\begin{tabular}{|c|c|c|c|c|c|c|c|c|c|c|}
\hline Yes & Yes & Yes & Can't tell & Can't tell & no & Can't tell & Can't tell & Yes & Can't tell & 6.5 \\
\hline Yes & Yes & Yes & Yes & Yes & Can't tell & Can't tell & Can't tell & Yes & Can't tell & 8.0 \\
\hline Yes & Yes & Can't tell & Can't tell & Yes & no & Can't tell & Can't tell & Yes & Can't tell & 6.5 \\
\hline Yes & Yes & & & & & & & & & \\
\hline & & Yes & Yes & Yes & Yes & Yes & Yes & Yes & Can't tell & 9.5 \\
\hline
\end{tabular}

Figures 


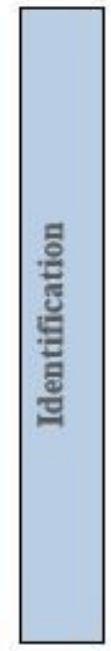

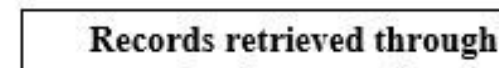
database search

$(n=2045)$
Records retrieved through pearl searching

$$
(\mathrm{n}=1)
$$

ע

吾

Records after removal of 610 duplicates

$(\mathrm{n}=1436)$

$\longrightarrow \quad \begin{gathered}\text { Excluded }(\mathbf{n}=\mathbf{1 3 2 6}) \\ \text { Study irrelevant }\end{gathered}$

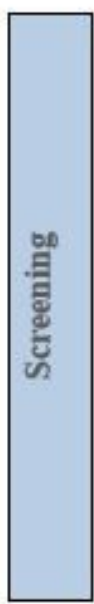

Records after screening by title

$$
(\mathrm{n}=110)
$$

Excluded $(\mathrm{n}=94)$

Different study designs $(\mathrm{n}=16)$

Different sample $(\mathrm{n}=30)$

Different outcomes $(\mathrm{n}=15)$

Not in scientific publication $(\mathrm{n}=17)$

Published before $2000(n=12)$

Not published in English $(n=4)$

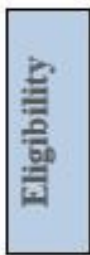

Records after abstracts and full-

text

$(\mathrm{n}=16)$
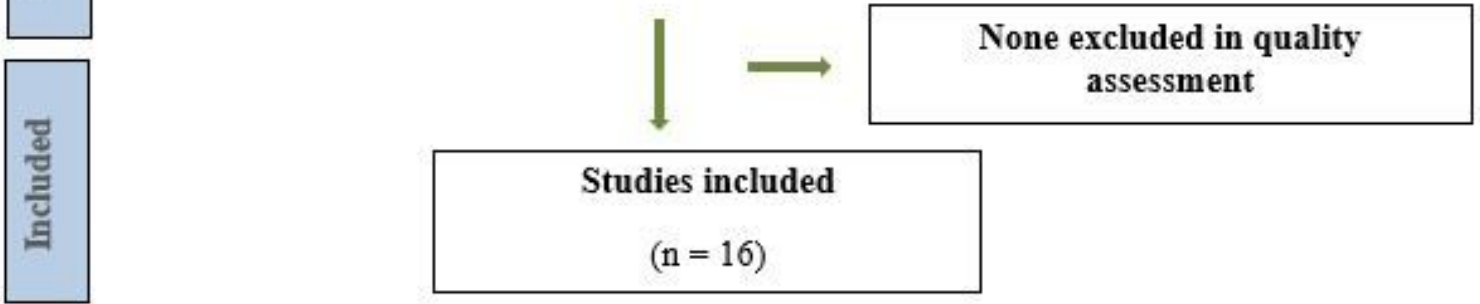

Studies included

$$
(\mathrm{n}=16)
$$

Figure 1

PRISMA flow chart

\section{Supplementary Files}

This is a list of supplementary files associated with this preprint. Click to download. 
- SupplementaryTable4.docx

Page 23/23 